\title{
전시리뷰
}

\section{《池大雅: 天衣無縫の旅の畫家》}

2018. $04.07-2018.05 .20$

京都国立博物館

干605-0931京都市東山区茶屋町527

\section{오 영 삼*}

2018년 4월 7일부터 5월 20일까지 에도시대 천재 남화가의 회고전이 일본 교토국립박물 관에서 열렸다. 18 세기 조선의 문인화가 정선(1676 1759)과 동시대의 南畫家인 이케노 타이가 (1723 1776)가 그 주인공이다. 특히 그의 산수화는 정선과 같이 소상도나 서호도를 비롯한 중 국 명승도의 방작과 자국 산천에 대한 유람을 통해 양식적으로 완성됐다는 점, 그리고 문인화의 이념을 재인식하여 산수화의 새로운 화제와 화풍을 개척했다는 점에서, 정선의 진경산수화와 국경을 뛰어넘는 동시대성을 공유한다. 그러나 당시 한국의 문인화가 사대부의 문인적 교양을 전제로 하고 있음에 비해 일본의 남화는 계급성을 뛰어넘는 취향과 소재, 그리고 기법이라는 장 르적 성격을 지니고 있다는 점에서 주의를 요한다.

마루야마 오쿄나 이토 작츄 등 동시대 교토의 개성파 화가와는 달리 요사 부손과 함께 남 화의 대성자로 꼽히는 이케노 타이가는 과욕하고 겸허한 인품을 상징하듯이 담박하고 화사한 문인화풍을 선보여, 에도 중기의 교토미술을 대표하는 화가로서 인기가 높다. 이번 전시는 85년 만에 열리는 대회고전인 만큼 이케노 타이가의 일대기를 160 점에 이르는 국보 및 중요문화재를 통해서 살펴보고자 했다고 한다.

전시는 제 1 장 천재의 등장-타이가의 주변인물, 제 2 장 중국화와 화보로부터 배우다, 제 3 장 지두화와 양식적 모색, 제 4 장 타이가의 그림과 글씨, 제 5 장 여행하는 화가-일본의 풍경을 그리 다, 제 6 장 타이가와 교쿠란, 제 7 장 천재의 본령 발휘-타이가 예술의 완성으로 구성되었다. 농사 를 가업으로 삼은 서민출신의 이케노 타이가는 4살 때 하급 관리였던 아버지를 여의고 불우한

* 교토여자대학교 강사 


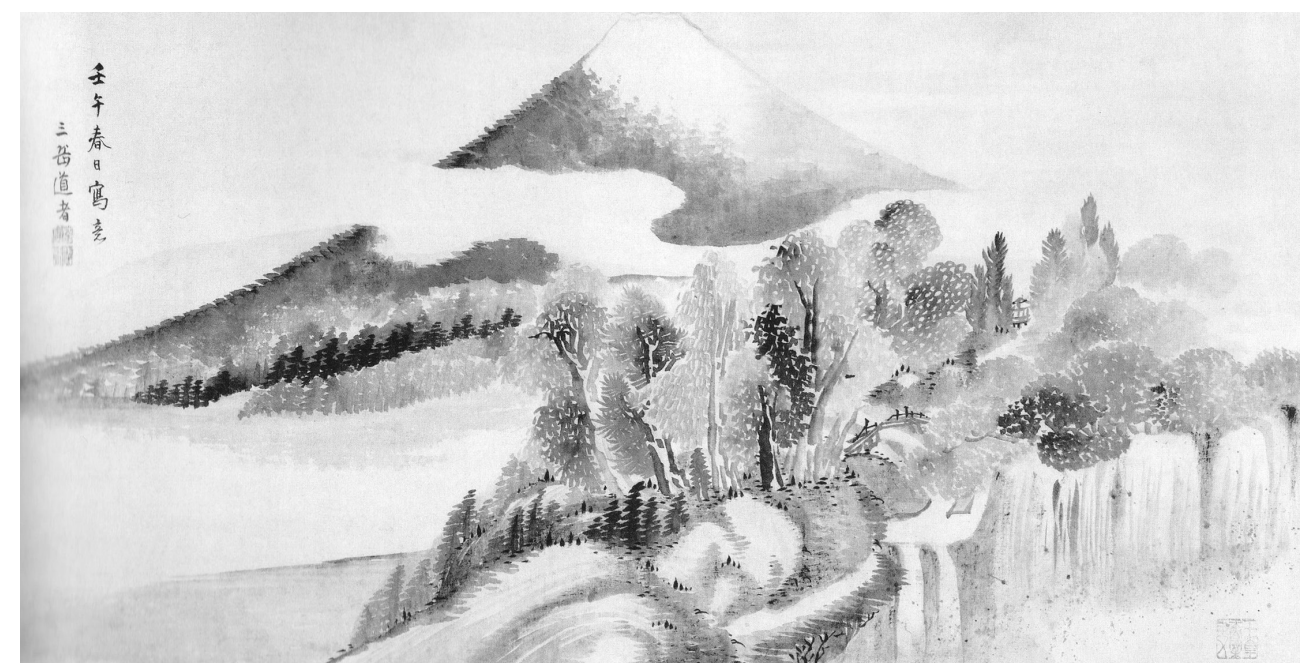

〈富士白絲瀧圖〉, 종이에 수묵담채, 사진참조.

환경에서 성장하였으며, 15 살 때는 중국에서 건너온 화보를 부채에 그려 생계를 꾸려나갔다. 그 러나 이미 7살 때부터 서예를 배워 그 재능을 인정받았고, 무엇보다도 이 시기 남화의 선구자인 柳澤淇園, 평생의 친구인 전각가 高芙蓉, 서예가 韓天壽를 만난 것이 문인화가로서 그의 화업 을 결정짓는 계기가 되었다.

제 1 장과 제 2 장에서는 그의 이러한 10 대와 20 대를 중심으로 시서화의 학습과 주변인물과 의 관계를 보여주는 작품이 전시되었다. 제 3 장과 제 4 장에서는 타이가의 화법에 영향을 미친 指 頭畫와 서예 관련 작품을 보여준다. 대상의 사실적 표현을 무시하고 날카로운 선(손톱)과 대담 한 면(손가락과 손바닥)의 리듬감을 추구하는 지두화는 햇빛을 듬뿍 머금은 색채와 어울려 독 특한 시각적 감흥을 전해주며, 전서와 예서 그리고 일본 가나와의 콜라보는 문인의 자유로운 생 명력을 화면에 불어넣어 주었다.

한편 타이가는 26세에 에도를 유람하다 내친김에 塩䆠와 松島까지 건너갔으며, 다음 해에 도 北陸·伊勢·出雲 등 일본 각지를 유력했다. 그 중에서도 30대에 떠난 일본의 명산 白山·立 山·富士山으로의 여행은 그의 산수화풍에 결정적인 영향을 미치게 된다. 웅대한 자연의 대서사 시에 대한 시각체험은 전통적인 필묵법과 공간감에 대한 비판적 인식을 고양시켰고, 이는 관념 적인 이국산수화를 대신할 진경화에 대한 창작욕으로 이어졌다. 여기에 부드러운 묵법, 세심한 점묘와 대담한 필선, 투명하고 명랑한 채색, 유머러스하고 소탈한 인물, 파격적인 여백과 구도, 격조 높은 소재가 더하여 이케노 타이가의 남화양식이 완성되는데 이 부분은 제 5 장에서 소개 
되었다.(사진)

아내 교쿠란과의 부부생활을 소개하는 제6장에 이어, 제7장에서는 40 대에 걸쳐 완성된 타이가의 대표작이 전시되었다. 〈산수인물화〉(수묵담채, 障屏畫 10면, 국보), 〈오백나한도〉(수 묵담채, 장병화 8면, 중요문화재), 〈서호도〉(수묵 담채, 장병화 8면, 중요문화재), 〈누각산수도〉 (수묵채색, 병풍 6곡 2척, 국보), 〈蘭亭曲水·龍山勝會圖〉(수묵담채, 병풍 6곡 2척, 중요문화재), 〈潚湘勝槐圖〉(수묵담채, 병풍 6곡 1척, 중요문화재), 〈柳下童子圖〉(수묵담채, 병풍 8곡 1척, 중 요문화재), 〈西湖春景·錢塘觀潮圖〉(수묵담채, 병풍 6곡 2척, 중요문화재), (十二個月離合山水 圖〉(수묵담채, 병풍 6곡 2척, 중요문화재),〈漁樂圖〉(수묵, 족자 1폭, 중요문화재),〈白雲紅樹圖〉 (수묵채색, 족자 1폭, 중요문화재), 〈洞庭赤壁圖〉(수묵채색, 족자 1권, 중요문화재), 〈十便十宜 圖〉 (수묵채색, 첩 20면, 국보), 〈東山淸音圖〉(수묵, 첩 16 면, 중요문화재) 등 다양한 형식의 문 인화가 총망라되었다.

전시 외에 주목을 끈 것은 지두화 체험 프로그램과 사진촬영 기념 이벤트, 그리고 기념 강 연회다. 특히 기념 강연회는 총 5 회로 「자유로운 영혼을 찾아서-이케노 타이가가 동경한 문인 세계」(佐々木 丞平, 교토국립박물관 관장), 「서호에 대한 동경-타이가의 명승도」(出光 佐千子, 아 오야마가쿠인대학 부교수/이데미츠미술관 학예원), 유람하는 화가의 그림_(福士 雄也, 교토국 립박물관 연구원), 「이케노 타이가의 그림-혹은 계란껍질과 노른자와의 관계」(佐藤康宏, 도쿄 대학 교수), 「타이가와 瞢村一十便十宜図를 중심으로」(小林忠, 오카다미술관 관장)가 준비되었 다. 강연회는 전시기간 중 매주 토요일에 한 번씩 박물관에서 열려, 강연자에게는 충분한 강연 시간을 제공하고, 청중에게는 용이한 참여를 유도해 주었다는 점이 인상 깊다. 